\title{
Community College Library 1965
}

\begin{abstract}
Questionnaires were circularized to the librarians and presidents of 334 public, coeducational junior colleges. Among subjects explored were characteristics of junior college faculty members, their library awareness, teaching methods, library aspirations and frustrations. Replies from the presidents and librarians are compared, similarities in attitudes observed and differences noted. Also given are the qualifications sought by junior college presidents in prospective directors of their libraries.
\end{abstract}

\section{$\mathbf{I}$} IN A CONTINUING EFForT to study the progress of community college library programming, a brief multiple-choice questionnaire was sent to all community college library directors in February, 1965. The important area of facultylibrary integration was selected for concentration. Later a questionnaire directed to the chief administrators of the community colleges whose library directors had responded explored their library attitudes and experiences. Assurance was given that the library directors, administrators and institutions would not be identified in any tabulation. The sixth edition of American Junior Colleges was utilized to provide a population of three hundred thirty-four public, coeducational junior colleges. Because there is no comprehensive listing of American com-

Dr. Wheeler is Associate Professor of Library Science in the University of Hawaii. In 1963, as part of the doctorate at $\mathrm{Co}$ lumbia University, the writer asked community college librarians to describe their programs. The project became known as "The Community College Library; An Appraisal of Current Practice," available as University Microfilm 65-4755. A book entitled "The Community College Library; A Plan for Action," based in part on this work, was published by Shoe String Press, 1964. munity colleges, it was necessary to ask recipients to disregard the questionnaires if they considered that their institutions were not functioning as community colleges. Therefore, the response of two hundred thirty librarians (68.86 per cent) perhaps is not fully indicative of the extent of their cooperation and support. Of the two hundred thirty chief administrators contacted, one hundred fourteen (49.56 per cent) responded. (Although "chief administrator" may refer to community college president, superintendent, dean, etc., the term "president" will be subsequently used.)

Community college teachers as viewed by their library directors are members of faculties ranging in size from ten to three hundred twenty-five, with the average faculty size between twentyfive and fifty. Two institutions rely entirely on part-time personnel, but twenty-five are able to recruit all fulltime teachers. Although 77 per cent of all of the teachers must meet some type of certification requirements, 64 per cent of these requirements can be satisfied on provisional or temporary bases. Fortythree of the two hundred thirty community colleges involved in this survey have faculties for which the master's degree is standard equipment, whereas the teachers of ninety-two have been pre- 
pared mainly by education courses. More than half report that their only other teaching experience had been in high schools. Although the majority of faculties were characterized as stable (as opposed to transient) by the librarians, community college teachers as individuals seem headed towards other kinds of employment-so that the librarians were prepared to list their destinations readily: about 40 per cent left for positions in four-year colleges; 25 per cent shifted to other types of teaching; and 9 per cent went into or returned to business.

The master's degree in a subject specialization topped the list of characteristics considered desirable for an effective community college faculty member from the point of view of the librarian. So-called "library-mindedness" was second, followed by broad liberal arts undergraduate preparation. Other characteristics many librarians hoped for in their faculty were community-mindedness, ongoing professional activities, and education coursework. It is interesting to note that when asked the same question (What characteristics do you consider most necessary for an effective community college faculty member?), most presidents also ranked the master's degree in subject-matter specialization first, but community-mindedness and ongoing professional activities followed in that order.

It was not unexpected that community college library directors found their English departments to be more libraryminded in teaching methods and attitudes than their science or business departments, although several social science departments were more libraryminded than English departments. Relating their courses to the library program least were the mathematics, technical, and science departments. Ways that community college faculty actively block an effective library program most frequently included the making of assignments before notifying the library ( 70.43 per cent of the librarians reported this as being the most frequent technique), assuming nonexistent library skills on the part of the students, and failing to recognize the importance of their part in the teaching and conveying of library attitudes and experiences. Other techniques frequently cited were failure to recognize the difference between library orientation and library instruction, over-use of text material, and failure to take some responsibility for their part of the library collection.

One hundred eighty-four ( 80 per cent) of the community colleges have faculty library committees, although the library director is not always a member. He is chairman, however, of one hundred (54 per cent) of them. The great majority of the committees were appointed by the administration without involvement of the librarian. Librarians who considered their library committee ineffective and undesirable, or who were unable to characterize its main function as advisory were in the minority; on the other hand, many avoided this whole area of questioning. Those who detailed their opinions as to why the library committee was not entirely satisfactory described committees which met to formulate policy and administer the library, to evaluate for accreditation, or which were dormant, did not have enough time, never met, or were uninformed or apathetic.

When community college presidents were asked their reasons for having library committees, only a fraction replied, which suggests that it is regarded as traditional, or "the thing to do." Most of the specific reasons given by presidents for having faculty library committees related to structuring policy and selecting books. And yet almost all indicated in their replies to the next question that they would characterize their library committee's main function as ad- 
visory. Most avoided the question of how the committee was established.

Almost all community college faculty regularly utilize reserve materials collections. Librarians reported only 17 per cent of their faculties as really misusing this technique, which is probably not a high percentage in public education today. A good proportion (72 per cent) were reported making assignments requiring use of the general book collection. About the same percentage recommend books regularly. But full utilization of the library staff as members of the teaching team is another matteronly about 39 per cent. Almost half of the community colleges have departmental faculty representatives. Likewise, about half have a substantial portion of the faculty working on advanced degrees.

The community college president's perception of his teachers, students, librarians, and library program is a revealing part of this picture of facultylibrary integration. Fully 40 per cent feel that their faculties fail to utilize library resources in their teaching. In the opinion of the presidents, ways in which this failure manifests itself most frequently include "not requiring enough reading," being "one textbook people," "making too little use of the library," "failing to encourage student use," and having limited knowledge of the collection. Also, 75 per cent of the community college presidents characterize their new students' previous library experience as being inadequate for college work.

One hundred ten of the one hundred fourteen community college presidents ranked the master's degree in library science from an accredited school among the basic characteristics of the capable library director. Second only to it is "excellent references from previous employers." Other characteristics of importance to the presidents-in descending order of frequency-are professional post-library-school experience, ongoing professional activities, audiovisual training or experience, teaching experience, and administrative experience. Can this be interpreted to mean that the presidents consider audiovisual and teaching experience more important than library administrative experience in the library director they recruit? Of least importance in their criteria for the capable community college library director's qualifications are origin in the community, publications, youth, "personality," and residence in the community.

Perhaps a final word should be said about the library programs which these library directors have been able to develop. Considering the number of volumes in the book collection as one among several significant factors in the effectiveness of the library program, 74 per cent of the responding community college libraries have less than the twenty thousand books recommended by the Junior College Library Standards. ${ }^{1}$ Of the six community college libraries having at least fifty thousand books, five are located in California. Another consideration of the Standards is the proportion of the student body which can be accommodated in the library at one time. Nineteen ( 8 per cent) of the community colleges meet the recommended 25 per cent of the full-time-equivalent student body.

This has been a brief report of demographic aspects of American community college library programs during the past year, with emphasis on their relationships to and with their faculties. It is not possible to make much interpretation of the data, but they may be useful in illuminating the contemporary picture.

${ }^{1}$ American Library Association. Association of College \& Research Libraries. "ALA Standards for Junior College Libraries," College \& Research Libraries, XXI (May 1960), 200-206; American Library \& Book Trade Annual, 1961. (New York: Bowker, 1960), pp. 125-32. 